\title{
Anthropometric correlates of blood pressure among school children in Nagpur city, central India: A cross-sectional study
}

\section{Deepak Kishanrao Lone, Sushma Subhash Thakre ${ }^{1}$, Avinash Moreshwar Borkar², Namita Navanit Deshmukh ${ }^{3}$, Subhash Bapurao Thakre ${ }^{4}$}

Departments of Community Medicine, Government Medical College, Aurangabad, ${ }^{1}$ Community Medicine, Indira Gandhi Government Medical College, Nagpur, ${ }^{2}$ Community Medicine, Shri Vasantrao Naik Government Medical College, Yeotmal, ${ }^{3}$ Community Medicine, Government Medical College, Akola, ${ }^{4}$ Community Medicine, Government Medical College, Nagpur, Maharashtra, India

Address for Correspondence: Dr. Deepak Kishanrao Lone, S/O Shri. Kishanrao Lone, B 5 S.K. Society, Triveninagar, Chaitnyanagar Road, Taroda, Nanded - 431 605, Maharashtra, India.

E-mail: dpklone@gmail.com

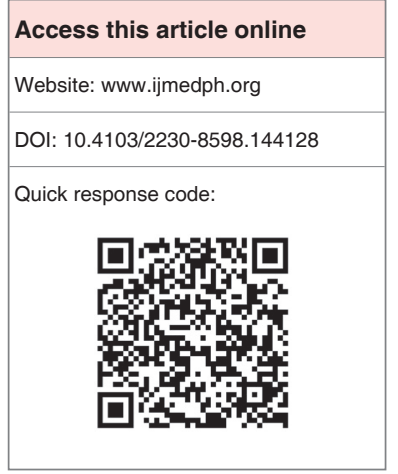

Context: On the basis of emerging evidence, it is now apparent that primary hypertension is detectable in the young and that it occurs commonly. The longterm health risks for hypertensive children and adolescents can be substantial. Early diagnosis of hypertension (HT) is an important strategy in its control. Previous studies have documented that hypertension may begin in adolescence, perhaps even in childhood. Aims: To determine the prevalence of hypertension and its correlation with anthropometric variables like height, weight and body mass index (BMI) among school-going children in Nagpur city, Central India. Settings and Design: Cross-sectional study done in one randomly selected school. Materials and Methods: School-going children aged between 12 and 16 years were included in the study. The weight and height were measured using a standard procedure. Blood pressure measurements were taken by a mercury sphygmomanometer. Hypertension was diagnosed if blood pressure was more than $95^{\text {th }}$ percentile for the age and height. The distributions of blood pressure by anthropometric characteristics were studied. Statistical Analysis Used: Mean, standard deviation, correlation coefficient and $\chi^{2}$ test were used for statistical analysis. Results: The overall prevalence of hypertension was found to be $11.77 \%$. Blood pressure of both genders appears to have positive correlation with anthropometric characteristics. Conclusions: Increase in anthropometric measurements like height, weight and BMI were found to be positively correlated with hypertension among school children in the present study.

Key words: Anthropometric measurements, hypertension, obesity, school children

\section{INTRODUCTION}

The prevalence of hypertension in children and adolescents seems to be increasing. ${ }^{[1]}$ This rise is partially because of the increasing prevalence of obesity among children and adolescents, as well as a growing awareness of this disease. There is evidence that hypertension in children and adolescents can lead to adult hypertension. ${ }^{[2,3]}$ Presence of hypertension in children and adolescents may contribute to the early development of coronary artery disease. Previous reports have shown that early development of atherosclerosis does exist in children and adolescents and may be associated with childhood hypertension. ${ }^{[4,5]}$

Appropriate early-stage diagnosis and interventions of hypertension in children and adolescents are important for reducing the risk of hypertension-related disorders in adults.

Keeping in view the seriousness of problem on one hand and lack of data about the prevalence of hypertension among school children in Nagpur on another, the present study was undertaken among the school children in Nagpur, to find out prevalence of hypertension and the relationship of hypertension with anthropometric variables like height, weight and body mass index (BMI).

\section{MATERIALS AND METHODS}

\section{Study design and setting}

A cross-sectional study among 450 school children was carried out in Nagpur city, from November 2011 to January 2012 in urban area under "Urban Health Training Centre, Gandhinagar, Indira 
Gandhi Govt. Medical College, Nagpur, Maharashtra, India. The study population comprised students aged 12 to 16 years living in the study area. Out of 13 schools, one school was selected by simple random sampling method. Students from $8^{\text {th }}$ to $10^{\text {th }}$ standard were included in the study. Permission from school authority was sought before the start of the study. Institutional ethical committee's clearance was sought before the start of the study.

\section{Data collection}

All students present in the classes at the time of interview were included in the study. In all, 450 students were interviewed. Every student was interviewed personally by an investigator using a selfadministered, pretested questionnaire.

General information regarding age, sex, religion, diet and addiction was collected using a pretested proforma. Anthropometric measurements such as weight was taken by a standardized weighing machine with accuracy up to $0.1 \mathrm{~kg}$ while height was measured using a standard stadiometer with accuracy up to $0.5 \mathrm{~cm}$. Blood pressure measurements were taken by a standard mercury sphygmomanometer. Three blood pressure measurements were taken at an interval of 5 minutes and the average of the three readings was used in the analysis.

Hypertension was diagnosed if blood pressure was more than $95^{\text {th }}$ percentile for the age and height. ${ }^{[6,7]} \mathrm{BMI}$ was calculated and classified according to $\mathrm{WHO}^{[8]}$ into five categories based on $\mathrm{z}$-scores. The cutoff values of $\mathrm{z}$-score for overweight are BMI $>+1 \mathrm{SD}$ (equivalent to BMI $25 \mathrm{~kg} / \mathrm{m}^{2}$ at 19 years), obesity $>+2 \mathrm{SD}$ (equivalent to BMI $30 \mathrm{~kg} / \mathrm{m}^{2}$ at 19 years), thinness $<-2 \mathrm{SD}$, severe thinness $<-3 \mathrm{SD}$ and normal within $-1 \mathrm{SD}$ to $+1 \mathrm{SD}$.

The distribution of blood pressure by anthropometric characteristics like height, weight and BMI were studied.

\section{Data analysis}

Data were entered in Microsoft Excel 2007 and analyzed with Graphpad Prism 5. Mean and standard deviation were calculated for categorical data and $\chi^{2}$ test was used as a test of significance. Pearson's Correlation coefficient was calculated to assess correlation between hypertension and height, weight and BMI of school children.

\section{RESULTS}

Out of 450 school children, there were 229 boys (50.89\%) and 221 girls $(49.11 \%)$. Total prevalence of hypertension was found to be $11.77 \%$ (53/450). The prevalence of hypertension among boys and girls were found to be almost same i.e., $11.79 \%(27 / 229)$ and $11.76 \%$ (26/221), respectively [Table 1].

The highest prevalence of hypertension was observed in 12 years of age in both sexes (22.22\% in boys and 30\% in girls) followed by 16 years $(11.32 \%$ in boys and $25 \%$ in girls.).

Mean age $( \pm$ SD) of the school children was $14.11 \pm 1.25$ years. Even with the short span of five years in the study (12-16 years) the mean blood pressure increased significantly with age $[\mathrm{r}=0.19$ for systolic blood pressure (SBP) and $r=0.07$ for diastolic blood pressure (DBP)] as evident from [Table 2]. The mean SBP of both sexes was $110.39 \mathrm{~mm} \mathrm{Hg}$ at the age of 12 years and $116.76 \mathrm{~mm}$ $\mathrm{Hg}$ at the age of 16 years, an increase of $6.37 \mathrm{~mm} \mathrm{Hg}$. Similarly, the increase of DBP was observed as $4.43 \mathrm{~mm} \mathrm{Hg}$ for the same group. So, the age effect was found to be more for SBP in the present study.

The result revealed that SBP and DBP of both sexes have a positive correlation $(P<0.01)$ with height; correlation of SBP with height was found to be 0.19 for boys and 0.21 for girls, and that of DBP were 0.21 and 0.26 for boys and girls, respectively [Table 3].

\begin{tabular}{|c|c|c|c|c|c|c|}
\hline \multirow[t]{2}{*}{ Age (yrs) } & \multicolumn{2}{|c|}{ Boys $n=229$} & \multicolumn{2}{|c|}{ Girls $n=221$} & \multicolumn{2}{|c|}{ Total $n=450$} \\
\hline & No. & HTN (\%) & No. & HTN (\%) & No. & HTN (\%) \\
\hline 12 & 27 & $6(22.22)$ & 30 & $9(30.00)$ & 57 & $15(26.31)$ \\
\hline 13 & 30 & $3(10.00)$ & 57 & $4(7.01)$ & 87 & 7 (8.04) \\
\hline 14 & 51 & $5(9.80)$ & 77 & $4(5.19)$ & 128 & $9(7.03)$ \\
\hline 15 & 68 & $7(10.29)$ & 37 & $4(10.81)$ & 105 & $11(10.47)$ \\
\hline 16 & 53 & $6(11.32)$ & 20 & $5(25.00)$ & 73 & $11(15.06)$ \\
\hline Total & $229(50.89)$ & $27(11.79)$ & $221(49.11)$ & $26(11.76)$ & $450(100)$ & $53(11.77)$ \\
\hline
\end{tabular}

\begin{tabular}{|c|c|c|c|c|c|c|c|c|c|}
\hline \multirow{2}{*}{$\begin{array}{l}\text { Age in } \\
\text { Years }\end{array}$} & \multicolumn{3}{|c|}{ Boys } & \multicolumn{3}{|c|}{ Girls } & \multicolumn{3}{|c|}{ Overall } \\
\hline & No. & $\begin{array}{c}\text { Mean } \\
\text { SBP }( \pm \text { SD) }\end{array}$ & $\begin{array}{c}\text { Mean } \\
\text { DBP }( \pm \text { SD) }\end{array}$ & No. & $\begin{array}{c}\text { Mean } \\
\text { SBP }( \pm \text { SD) }\end{array}$ & $\begin{array}{c}\text { Mean } \\
\text { DBP }( \pm \text { SD) }\end{array}$ & No. & $\begin{array}{c}\text { Mean } \\
\text { SBP }( \pm \text { SD) }\end{array}$ & $\begin{array}{c}\text { Mean } \\
\text { DBP }( \pm \text { SD) }\end{array}$ \\
\hline 12 & 27 & $110.54( \pm 11.06)$ & $72.60( \pm 8.62)$ & 30 & $110.24( \pm 10.91)$ & $72.60( \pm 8.62)$ & 57 & $110.39( \pm 10.90)$ & $72.60( \pm 8.68)$ \\
\hline 13 & 30 & $114.77( \pm 11.44)$ & $74.21( \pm 9.23)$ & 57 & $114.31( \pm 11.27)$ & $74.60( \pm 9.02)$ & 87 & $114.54( \pm 11.25)$ & $74.40( \pm 9.01)$ \\
\hline 14 & 51 & $115.16( \pm 11.16)$ & $76.62( \pm 8.93)$ & 77 & $115.29( \pm 11.03)$ & $75.70( \pm 8.93)$ & 128 & $115.22( \pm 10.94)$ & $76.16( \pm 8.80)$ \\
\hline 15 & 68 & $115.26( \pm 11.01)$ & $76.87( \pm 8.92)$ & 37 & $115.68( \pm 11.11)$ & $75.86( \pm 9.09)$ & 105 & $115.47( \pm 11.01)$ & $76.36( \pm 8.92)$ \\
\hline 16 & 53 & $116.99( \pm 11.36)$ & $77.96( \pm 9.00)$ & 20 & $116.54( \pm 11.46)$ & $76.11( \pm 9.15)$ & 73 & $116.76( \pm 11.36)$ & $77.03( \pm 9.00)$ \\
\hline
\end{tabular}


In both sexes, a rise is observed in mean SBP and DBP with increase in mean weight [Table 4]. In the present study, correlation coefficient of SBP with weight was 0.35 and 0.36 and that of DBP was 0.30 and 0.33 in boys and girls, respectively.

In our study, $32(7.11 \%)$ children were overweight and obese and $357(79.33 \%)$ were having normal BMI, while the remaining 61 $(13.56 \%)$ were underweight [Table 5]. Among these 32 children, $18(56.25 \%)$ were hypertensive; of the remaining 418 children, $35(8.37 \%)$ were hypertensive [Table 6]. When this association of higher BMI with hypertension was studied, it was found to be statistically significant $(P=0.0000)$. Also, the result revealed that SBP and DBP of both sexes have a positive correlation $(P<0.01)$ with BMI; correlation of SBP with BMI was found to be 0.39 for boys and 0.21 for girls, and that of DBP with BMI was 0.20 and 0.32 in boys and girls, respectively.

\section{DISCUSSION}

In our study, we found $11.77 \%$ prevalence of hypertension among adolescents. Durrani et al. ${ }^{[9]}$ reported $9.4 \%$ prevalence of hypertension in the same age group i.e., 12-16 years in Aligarh. Also similar prevalence $\left(11.7 \%\right.$ ) was reported by Chadha et al. ${ }^{[10]}$ in
Delhi. Other studies done in different parts of India reported a vast range in the prevalence of hypertension in children and adolescents showing as high as $21.5 \%$ to as low as $3.67 \% .^{[11,12]}$ Other researchers across India also found varied prevalence of hypertension among adolescents. Taksande et al..$^{[13]}$ reported $5.75 \%$ in rural Wardha, Khan et al. ${ }^{[14]}$ reported $9.78 \%$ prevalence in Ahmedabad, Mane et al. ${ }^{[15]}$ found $4 \%$ prevalence in Western India. In New Delhi, $7.84 \%$ prevalence was reported by Singh et al. ${ }^{[16]}$ Also, Borade et al. ${ }^{[17]}$ reported $10.91 \%$ prevalence of hypertension in Pune among adolescents. This varied prevalence may be due to different criteria used for diagnosis of hypertension and varied socio-cultural and socioeconomic environment of the adolescents residing in different parts of India.

We found slightly lower prevalence of hypertension in girls $(11.76 \%)$ than in boys $(11.79 \%)$. This difference in prevalence of hypertension was not found to be statistically significant $(P>0.05)$. Similar results were reported by Prabhjot et al..$^{[18]}$ in Amritsar, Punjab, with $8.3 \%$ prevalence of hypertension in boys and $6.52 \%$ prevalence in girls. But Durrani et al. ${ }^{[9]}$ found lower prevalence of hypertension in boys $(9.36 \%)$ than in girls $(9.4 \%)$. Also, there is varied prevalence of hypertension in different age groups. The difference in patterns of blood pressure between males and females and varied prevalence

\begin{tabular}{|c|c|c|c|c|c|c|c|c|c|}
\hline \multirow{2}{*}{$\begin{array}{l}\text { Range } \\
\text { height }\end{array}$} & \multicolumn{3}{|c|}{ Boys } & \multicolumn{3}{|c|}{ Girls } & \multicolumn{3}{|c|}{ Overall } \\
\hline & No. & $\begin{array}{c}\text { Mean } \\
\text { SBP }( \pm \text { SD) }\end{array}$ & $\begin{array}{c}\text { Mean } \\
\text { DBP }( \pm \text { SD) }\end{array}$ & No. & $\begin{array}{c}\text { Mean } \\
\text { SBP }( \pm \text { SD) }\end{array}$ & $\begin{array}{c}\text { Mean } \\
\text { DBP }( \pm \text { SD) }\end{array}$ & No. & $\begin{array}{c}\text { Mean } \\
\text { SBP }( \pm \text { SD) }\end{array}$ & $\begin{array}{c}\text { Mean } \\
\text { DBP (+ SD) }\end{array}$ \\
\hline $1.31-1.40$ & 25 & $115.08( \pm 11.01)$ & $74.68( \pm 8.85)$ & 33 & $115.38( \pm 11.06)$ & $74.97( \pm 9.02)$ & 58 & $115.01(+11.00)$ & $74.71(+8.78)$ \\
\hline $1.41-150$ & 49 & $116.06(+11.35)$ & $75.07(+8.97)$ & 87 & $116.20(+11.44)$ & $75.06(+9.09)$ & 136 & $115.74(+11.22)$ & $75.00(+8.97)$ \\
\hline $1.51-1.60$ & 59 & $116.05(+11.36)$ & $75.01(+75.01)$ & 82 & $116.05(+11.39)$ & $75.07(+8.96)$ & 141 & $116.05(+11.36)$ & $75.01(+9.00)$ \\
\hline $1.61-1.70$ & 63 & $116.05( \pm 11.40)$ & $75.03( \pm 9.00)$ & 16 & $116.26( \pm 11.45)$ & $75.08( \pm 9.04)$ & 79 & $116.05( \pm 11.40)$ & $75.03( \pm 9.00)$ \\
\hline $1.71-1.80$ & 33 & $116.06( \pm 11.43)$ & $74.92( \pm 9.06)$ & 03 & $116.33( \pm 11.49)$ & $74.66( \pm 9.31)$ & 36 & $116.06( \pm 11.43)$ & $74.92( \pm 9.06)$ \\
\hline
\end{tabular}

Pearson correlation coefficient $(r)$, Height $(\mathrm{m})$ overall $=0.19(\mathrm{SBP})$ and 0.24 (DBP), $r($ Boys $)=0.19(\mathrm{SBP})$ and 0.24 (DBP), $r($ Girls $)=0.21$ (SBP) and 0.26 (DBP)

\begin{tabular}{|c|c|c|c|c|c|c|c|c|c|}
\hline \multirow{2}{*}{$\begin{array}{l}\text { Range } \\
\text { weight }(\mathrm{kg})\end{array}$} & \multicolumn{3}{|c|}{ Boys } & \multicolumn{3}{|c|}{ Girls } & \multicolumn{3}{|c|}{ Overall } \\
\hline & No. & $\begin{array}{c}\text { Mean } \\
\text { SBP }( \pm \text { SD) } \\
\end{array}$ & $\begin{array}{c}\text { Mean } \\
\text { DBP }( \pm \text { SD) } \\
\end{array}$ & No. & $\begin{array}{c}\text { Mean } \\
\text { SBP }( \pm \text { SD) }\end{array}$ & $\begin{array}{c}\text { Mean } \\
\text { DBP }( \pm \text { SD) } \\
\end{array}$ & No. & $\begin{array}{c}\text { Mean } \\
\text { SBP }( \pm \text { SD) }\end{array}$ & $\begin{array}{c}\text { Mean } \\
\text { DBP }( \pm \text { SD) } \\
\end{array}$ \\
\hline $21-30$ & 24 & $116.02(+11.10)$ & $74.54(+8.81)$ & 9 & $115.81(+11.00)$ & $74.31(+8.85)$ & 33 & $115.81(+11.00)$ & $74.31(+8.85)$ \\
\hline $31-40$ & 64 & $115.89(+11.31)$ & $74.99(+8.96)$ & 82 & $115.29(+11.05)$ & $74.88(+8.98)$ & 146 & $115.00(+11.31)$ & $74.97(+8.96)$ \\
\hline $41-50$ & 92 & $116.00(+11.37)$ & $74.97(+9.00)$ & 107 & $116.05(+11.39)$ & $75.07(+8.96)$ & 199 & $116.00(+11.37)$ & $74.97(+9.00)$ \\
\hline $51-60$ & 38 & $116.14(+11.44)$ & $74.99(+9.05)$ & 19 & $116.26(+11.45)$ & $75.08(+9.04)$ & 57 & $116.14(+11.44)$ & $74.99(+9.07)$ \\
\hline $61-70$ & 11 & $116.05(+11.41)$ & $74.99(+9.09)$ & 04 & $115.34(+10.95)$ & $74.88(+9.17)$ & 15 & $116.05(+11.41)$ & $74.99(+9.09)$ \\
\hline
\end{tabular}

Pearson correlation coefficient $(r)$, Weight $(\mathrm{kg})$ overall $=0.35(\mathrm{SBP})$ and $0.37(\mathrm{DBP}), \mathrm{r}($ Boys $)=0.35(\mathrm{SBP})$ and $0.30(\mathrm{DBP}), r(\mathrm{Girls})=0.36(\mathrm{SBP})$ and $0.33(\mathrm{DBP})$

\begin{tabular}{|c|c|c|c|c|c|c|c|c|c|}
\hline \multirow{2}{*}{$\begin{array}{l}\text { BMI category }\left(\mathrm{kg} / \mathrm{m}^{2}\right) \\
\text { (Z-scores) }\end{array}$} & \multicolumn{3}{|c|}{ Boys } & \multicolumn{3}{|c|}{ Girls } & \multicolumn{3}{|c|}{ Overall } \\
\hline & No & $\begin{array}{c}\text { Mean } \\
\text { SBP (+SD) } \\
\end{array}$ & $\begin{array}{c}\text { Mean } \\
\text { DBP (+SD) }\end{array}$ & No & $\begin{array}{c}\text { Mean } \\
\text { SBP (+SD) }\end{array}$ & $\begin{array}{c}\text { Mean } \\
\text { DBP (+SD) }\end{array}$ & No & $\begin{array}{c}\text { Mean } \\
\text { SBP (+SD) }\end{array}$ & $\begin{array}{c}\text { Mean } \\
\text { DBP (+SD) }\end{array}$ \\
\hline Normal (-1SD to +1SD) & 162 & $116.04(+11.36)$ & $74.97(+9.01)$ & 195 & $116.07(+11.38)$ & $75.07(+8.95)$ & 357 & $116.05(+11.35)$ & $74.99(+9.00)$ \\
\hline Overweight (>+1SD) & 13 & $115,85(+11.29)$ & $75.01(+8.95)$ & 17 & $116.17(+11.32)$ & $75.00(+9.19)$ & 30 & $115.85(+11.29)$ & $75.01(+8.95)$ \\
\hline Obese $(>+2 S D)$ & 02 & $115.23(+11.07)$ & $74.71(+8.89)$ & 00 & - & - & 02 & $115.23(+11.07)$ & $74.71(+8.89)$ \\
\hline Thinness (<-2SD) & 35 & $116.12(+11.43)$ & $74.93(+9.09)$ & 09 & $115.57(+11.24)$ & $74.67(+9.12)$ & 44 & $116.12(+11.43)$ & $74.93(+9.09)$ \\
\hline Severe Thinness $(<-3 S D)$ & 17 & $115.69( \pm 11.2)$ & $74.96(+8.96)$ & 00 & - & - & 17 & $115.69(+11.2)$ & $74.96(+8.96)$ \\
\hline
\end{tabular}




\begin{tabular}{lccc}
$\begin{array}{l}\text { Table 6: Association of hypertension to higher } \\
\text { BMI category }\end{array}$ & \multicolumn{2}{c}{ Hypertension } & Total \\
\cline { 2 - 3 } BMI category & Present & Absent & \\
\hline $\begin{array}{l}\text { Overweight + Obese } \\
\text { Normal + Thinness + } \\
\text { Severe Thinness }\end{array}$ & $35(86.25)$ & $14(43.75)$ & $32(7.11)$ \\
Total & $53(11.77)$ & $383(91.63)$ & $418(92.89)$ \\
\hline
\end{tabular}

$P$ value $=0.0000, \chi^{2}=63.88, \mathrm{df}=1 \mathrm{VHS}$

of hypertension in different age groups are probably related to certain biological, psychosocial factors and puberty timings. ${ }^{[13]}$

In our study, we found the positive correlation between hypertension and the anthropometric variables like height $(P<0.0001)$, weight $(P<0.0001)$ and BMI $(P<0.0001)$. Overall coefficient of correlation of height with blood pressure was 0.19 for SBP and 0.24 for DBP. SBP and DBP of both genders established the positive correlation $(P<0.0001)$ with height, which is in accordance with the findings of Durrani et al,,$^{[9]}$ Gupta et al. ${ }^{[19]}$ and Saha et al. ${ }^{[20]}$

The correlation coefficient of SBP and DBP of both genders also showed a positive correlation with weight [SBP $r=0.35$ (boys) and 0.36 (girls) and DBP r $=0.30$ (boys) and 0.33 (girls)], which agreed with the finding of Durrai et al. ${ }^{[9]}[\mathrm{SBP} r=0.47$ (boys) and 0.50 (girls) and DBP r $=0.46$ (boys) and 0.42 (girls) $]$ and Gupta et al. ${ }^{[19]}[\mathrm{SBP} r=$ 0.55 (boys) and 0.58 (girls) and DBP r $=0.61$ (boys) and 0.52 (girls)].

Similarly other studies done in different parts of India also showed a positive correlation of SBP and DBP with height and weight of adolescents. Taksande et al. ${ }^{[13]}$ showed positive correlation of height with SBP $(r=0.39)$ and with DBP $(r=0.31)$. They also showed positive correlation between weight of adolescents and SBP $(r=$ $0.39)$ and with DBP $(r=0.28)$. Saha et al. ${ }^{[20]}$ also reported significant positive correlation of height [SBP r $=0.62$ (boys) and 0.54 (girls) and DBP r $=0.52$ (boys and girls)] and weight [SBP r $=0.77$ (boys) and 0.76 (girls) and DBP r $=0.76$ (boys) and 0.63 (girls)] with SBP and DBP of both genders.

Overall, the mean BMI of the study participants was found to be $18.11 \pm 2.68$, while mean BMI of boys was $17.38 \pm 2.52$ and that of girls was $18.87 \pm 2.64$. Similar results were reported by Kapil et al. ${ }^{[21]}$ who found that mean BMI for boys was $20.76 \mathrm{~kg} / \mathrm{m}^{2}$ and for girls it was $21.02 \mathrm{~kg} / \mathrm{m}^{2}$. Mane et al. ${ }^{[15]}$ also reported a BMI of $19.11 \mathrm{~kg} / \mathrm{m}^{2}$ for boys and $18.92 \mathrm{~kg} / \mathrm{m}^{2}$ for girls. Rahman et al. ${ }^{[22]}$ also reported a mean BMI of $18.5 \pm 4.3$ in a study done among school children (mean age $14 \pm 1.3$ years) in Karachi, Pakistan. These differences in BMI can be attributed to socioeconomic and environmental differences.

In the present study, we found $7.11 \%$ overweight and obese adolescents. Prevalence of hypertension among these was $56.25 \%$ $(18 / 32)$ as compared to the prevalence in normal and other children i.e., $8.37 \%$ [Table 6]. And this difference in the prevalence was found to be statistically significant $(P=0.0000)$. Raj et al. ${ }^{[23]}$ in 2007 determined the relationship of obesity with blood pressure.
Systolic or diastolic incident hypertension was found in $17.34 \%$ of overweight children versus $10.1 \%$ of the remaining students. Desai et al..$^{[24]}$ reported $5 \%$ prevalence of overweight adolescents in Surat city while Rahman et al. ${ }^{[22]}$ estimated $7 \%$ and $2 \%$ prevalence of overweight and obesity, respectively, which are similar findings to our study.

It is evident from this school-based epidemiological study that increase in BMI predisposes the adolescent individual to higher blood pressure and subsequently, hypertension. A statistical significance was found between overweight/obesity and hypertension in the present study. A similar finding was also reported elsewhere in India; Chakraborty et al. ${ }^{[12]}$ found $17.12 \%$ prevalence of overweight and $2.45 \%$ prevalence of obesity among adolescents of Kolkata city. They also found the statistically significant association between presence of hypertension and overweight and obesity $(P<0.001)$. Khan et al. ${ }^{[14]}$ reported $10.44 \%$ and $5.77 \%$ prevalence of overweight and obesity, respectively in adolescent school boys (12-19 years) in Ahmedabad city. Nanaware et al. ${ }^{[25]}$ showed significantly positive correlation between BMI and SBP $(\mathrm{r}=0.81, P<0.001)$ and with DBP $(r=0.72, P<0.01)$ in the age group of $13-16$ years.

Mane et al. ${ }^{[15]}$ also reported that the increasing BMI contributed to increase in $\operatorname{SBP}(P=0.000)$ and $\operatorname{DBP}(P=0.000)$ in their study. Shah et al. ${ }^{[26]}$ reported $8.94 \%$ prevalence of obesity and $20.9 \%$ prevalence of hypertension among adolescents of Surat city. They also found that the prevalence of hypertension adolescents was more in obese as compared to normal $(P=0.0034)$. Thus, our findings are consistent with the above studies.

\section{CONCLUSION}

Increase in anthropometric measurements like height, weight and BMI were found to be positively correlated with hypertension among school children in the present study.

\section{Recommendation}

Children must be screened to detect and check the presence of hypertension and influencing factor like overweight. High risk children who are overweight and obese should be given close follow-ups. Extended research is required to find out association of hypertension and various risk factors like diet, regular exercise and weight reduction. Appropriate health education need to be given at home and school so that these risk factors can be eliminated in early stages itself.

\section{Limitations}

This was a cross-sectional study mainly intended to get blood pressure distribution and its relation to anthropometric measurements among school children, so to obtain a more precise idea about trends of blood pressure some longitudinal studies may be required. Further similar studies can be done with a larger sample size in this region to get more accurate results of blood pressure for children and adolescents. 


\section{ACKNOWLEDGMENT}

Authors thank the school authorities for giving permission to conduct this study. Authors also thank the Department of PSM, Indira Gandhi Govt. Medical College, Nagpur, for all their support and encouragement.

\section{REFERENCES}

1. Sarof JM, Lai D, Turner J, Poffenbarger T, Portman RJ. Overweight, ethnicity, and prevalence of hypertension in school-aged children. Pediatrics 2004;113:475-82.

2. Lauer RM, Clarke WR. Childhood risk factors for high adult blood pressure: The Muscatine Study. Pediatrics 1989;84:633-41.

3. Kiessling SG, McClanahan KK, Omer HA. Obesity, hypertension, and mental health evaluation in adolescents: A comprehensive approach. Int J Adolesc Med Health 2008;20:5-15.

4. Berenson GS, Srinivasan SR, Bao W, Newman III WP, Tracy RE, Wattigney WA. Association between multiple cardiovascular risk factors and atherosclerosis in children and young adults. The Bogalusa Heart Study. N Engl J Med 1998;338:1650-6.

5. Berenson GS. Childhood risk factors predict adult risk associated with subclinical cardiovascular disease. The Bogalusa Heart Study. Am J Cardiol 2002;90:3-7L.

6. National High Blood Pressure Education Programme. Working Group on high blood pressure in children and adolescents Fourth report on the diagnosis, evaluation, and treatment, of high blood pressure in children and adolescents.Pediatrics 2004;114:555-76.

7. Chobanian AV, Bakris GL, Black HR, Cushman WC, Green LA, Izzo JL Jr, et al. National Heart, Lung, and Blood Institute Joint National Committee on Prevention, Detection, Evaluation, and Treatment of High Blood Pressure; National High Blood Pressure Education Program Coordinating Committee. The Seventh Report of the Joint National Committee on Prevention, Detection, Evaluation and Treatments of High Blood Pressure: The JNC 7 report. JAMA 2003;19:2560-72.

8. World Health Organization. World Health Organization Child Growth Standards. Available from: http://www.who.int/growthref/who2007_bmi_ for_age/en/index.html [Last accessed on 2014 Apr 15].

9. Durrani AM, Waseem F. Blood pressure distribution and its relation to anthropometric measurements among school children in Aligarh. Indian J Public Health 2011;55:121-4.

10. Chadha SL, Tandon R, Shekhawat S, Gopinath N. An epidemiological study of blood pressure in school children (5-14 years) in Delhi. Indian Heart J 1999;51:178-82.

11. Sundar J, Joseph S, Parameswari S, Valarmarthi S, Kalpana S, Shantharam D. Prevalence and determinants of hypertension among urban school children in the age group of 13-17 years in, Chennai, Tamil Nadu. IOSR J Dent Med Sci 2013;8:14-20.

12. Chakraborty P, Dey S, Pal R, Kar S, Zaman FA, Pal S. Obesity in Kolkata children: Magnitude in relationship to hypertension. J Nat Sci Biol Med 2011;2:101-6

13. Taksande A, Chaturvedi P, Vilhekar K, Jain M. Distribution of blood pressure in school going children in rural area of Wardha district, Maharashtra, India. Ann Pediatr Cardiol 2008;1:101-6.

14. Khan MI, Lala MK, Patil R, Mathur HN, Chauhan NT. A study of the risk factors and the prevalence of hypertension in the adolescent school boys of Ahmedabad city. J Clin Diagn Res 2010:3348-54.

15. Mane SV, Agarkhedkar SR, Karwa DS, Pande V, Singhania SS, Karambelkar GR. Study of risk factors for lifestyle diseases among adolescents in Western India. Int J Pharm Biomed Sci 2012;3:224-8.

16. Singh AK, Maheshwari A, Sharma N, Anand K. Lifestyle associated risk factors in adolescents. Indian J Pediatr 2006;73:901-6.

17. Borade A, Kadam GS, Bhide G, Dhongade R. Study of blood pressure and blood sugar levels in adolescence and comparison with body mass index. Indian J Med Sci 2011;65:297-310.

18. Prabhjot A, Kaur N, Kumari K, Sidhu S. Variation in blood pressure among school children of Amritsar (Punjab). Anthropologist 2005;7:201-4.

19. Gupta AK, Ahmad AJ. Normal blood pressures and the evaluation of sustained blood pressure elevation in childhood. Indian Pediatr 1990;27:33-42.

20. Saha I, Raut DK, Paul B. Anthropometric correlates of adolescent blood pressure. Indian J Public Health 2007;51:190-2.

21. Kapil U, Kaur S, Singh P. Pattern of chronic diseases amongst adolescent obese children in developing countries. Curr Sci 2005;88:1052-6.

22. Rahman AJ, Qamar FN, Ashraf S, Khowaja ZA, Tariq SB, Naeem H. Prevalence of hypertension in healthy school children in Pakistan and its relationship with body mass index, proteinuria and hematuria. Saudi J Kidney Dis Transpl 2013;24:408-12.

23. Raj M, Sundaram KR, Paul M, Deepa AS, Kumar RK. Obesity in Indian children: Time trends and relationship with hypertension. Natl Med J India 2007;20:288-93.

24. Desai B, Solanky P, Baxi RK, Bansal R. Health and nutritional profile of school going adolescents in Surat city. Healthline 2012;3:14-7.

25. Nanaware NL, Gavkare AM, Surdi AD. Study of correlation of body mass index (BMI) with blood pressure in school going children and adolescents. Int J Recent Trends Sci Technol 2011;1:20-6.

26. Shah SS, Dave BR, Sharma AA, Desai AR. Prevalence of hypertension and association of obesity with hypertension in school going children of Surat city, Western India. Online J Health Allied Sci 2013;12:5. Available from: http://www.ojhas.org/issue46/2013-2-5. html [Last accessed on 2014 Mar 22].

How to cite this article: Lone DK, Thakre SS, Borkar AM, Deshmukh NN, Thakre SB. Anthropometric correlates of blood pressure among school children in Nagpur city, central India: A cross-sectional study. Int J Med Public Health 2014;4:436-40.

Source of Support: Nil, Conflict of Interest: None declared. 